\section{Onion Seed Size, Weight, and Elemental Content Affect Germination and Bulb Yield}

\author{
Sayed Gamiely ${ }^{1}$ D.A. Smittle ${ }^{2}$, and H.A. Mills* \\ Department of Horticulture, University of Georgia, Athens, GA 30602
}

\section{G.I. Banna \\ University of Mansoura, Mansoura, Egypt}

Additional index words. Allium cepa

Abstract. Yields of 'Granex 33' and 'Behairy' onions (Allium cepa) closely correlated with the weight of the seeds used to establish the stand. Elemental content was consistently higher in heavier seeds, but elemental concentrations in the seeds were generally negatively related to seed weight, onion growth, and yield. A combined size-aspiration grading was an effective means of eliminating seed with low-yield potential.
Direct seeding of onions is an economically desirable cultural practice (Austin, 1963). Variability in onion seed germination and seedling vigor reduces the feasibility of direct seeding. The relationship between onion seed physical and chemical characteristics and germination, vigor, growth, and bulb yield have not been clearly delineated. Seeds of many horticultural crops have been separated by size, weight, density, and color (Brandenburg, 1977; Smith et al., 1973; Smith and Camper, 1975; Smittle et al, 1976; Smittle, 1982). Separation by seed weight and/or density, as well as seed size, offers a means of improving seedling vigor and/or yield for many crops (Hartwig and Edwards, 1970; Johnson and Ludders, 1974; Smith et al., 1973; Smith and Camper, 1975; Smittle, 1982); The objectives of this investigation were to determine the relationships between seed physical and chemical characteristics and germination, growth, and yield of 'Granex 33 ' and 'Behairy' onion.

'Granex 33' seeds were separated with screens into two groups identified as small ( 2.10 to $2.36 \mathrm{~mm})$ or large (2.37 to 2.76 $\mathrm{mm})$. Small, large, and nonsized seeds were either used directly or were separated in a vertical air column into light and heavy groups were analyzed for seed weight, germination and $\mathrm{Zn}$ elemental concentrations (Isaac and Johnson, 1976; Jones, 1977). Seedling emergence yields were determined by direct seeding into a Tifton loamy sand soil. Plots plot) in Oct. 1986. Seeds were spaced $10 \mathrm{~cm}$ apart in four rows spaced $20 \mathrm{~cm}$ apart on a $1.8-\mathrm{m}$ bed. Cultural practices were as rec-

Received for publication 22 May 1989. The cost the payment of page charges. Under postal regulations, this paper therefore must be hereby marked advertisement solely to indicate this fact.

'Graduate Student.

${ }^{2}$ Professor of Horticulture. (Smittle et al.; 1976). These nine seed grades produced by the size-aspiration separation at $10 \mathrm{C}$, and $\mathrm{N}, \mathrm{P}, \mathrm{K}, \mathrm{Ca}, \mathrm{Mg}, \mathrm{Mn}, \mathrm{Cu}, \mathrm{Mg}$, at Tifton, Ga., were hand-seeded (200 per of publishing this paper was defrayed in part by ommended for Georgia (Vavrina and Granberry, 1988). Bulbs were harvested in May 1987 and field cured for 3 days. The tops were removed, and the bulbs were grouped into small ( 25 to $57 \mathrm{~mm}$ ), medium ( 57 to 83 $\mathrm{mm}$ ), and large ( > $83 \mathrm{~mm}$ ) grades. The experimental design was a randomized complete block with four replications.

A second study was conducted with 'Behairy', the main onion cultivar grown in Egypt. Commercial samples of 'Behairy' seed were separated by aspiration into light, medium, and heavy grades. Seed planting, cultural practices, and data collection were the same as used for the 'Granex 33' experiment. The experimental design was a randomized complete block with five replications. All data were subjected to analyses of variance, with means separated by Duncan's multiple range test $(0.05 \%)$.

'Granex 33'. The combination of size and aspiration grading separated 'Granex 33' seeds into weight groups ranging from 1.8 to 3.4 $\mathrm{mg} /$ seed (Table 1). Seedling emergence under field conditions closely paralleled the seed weights of the grades. Germination at 10C showed a similar response to seed weight differences, although germination of the small- heavy seed grade was greater than would be indicated by seed weight. Seed grading resulted in large final stand differences. In general, the number of plants in the final stand increased as seed weight increased, although survival of plants of the nonsizedheavy seed grade was greater than would be expected based on seed weight. Total and marketable bulb yields were highest with the nonsized-heavy grade and least with the smalllight grade. Correlation analyses showed close positive relationships $\left(\mathrm{R}^{2}\right)$ between onion seed weight and germination at $10 \mathrm{C}$, field emergence, final stand, total bulb yield, and marketable bulb yield (Table 1). Differences in seed weight accounted for the following variations: $81 \%$ for germination at $10 \mathrm{C}, 92 \%$ for field emergence, $86 \%$ for final stand, $83 \%$ for total bulb yield, and $79 \%$ for marketable bulb yield.

Elemental concentrations in the seeds were negatively correlated, but elemental content per seed was positively correlated with germination at $10 \mathrm{C}$, field emergence, final stand, total bulb yield, and marketable bulb yield (Table 2). These growth and yield responses were more closely related to seed weight than to elemental content. The negative relationships between elemental concentrations and onion growth and yield responses suggest that these responses are positively related to seed components, such as storage carbohydrates, that are also negatively related to elemental concentrations. These results are in agreement with earlier reports (Smith et al., 1973; Smith and Camper, 1975; Smittle, 1982) that showed seed weight is the primary factor affecting seed-related responses. Smittle (1982) found that elemental concentrations in radish seeds were not significantly correlated with root weights.

These data strongly suggest that separation of 'Granex 33' onion seed by weight is desirable for maximizing germination, emergence, and yield. Nutrient reserves are greater for the heaviest seed and would support germination and emergence to a greater extent.

'Behairy'. Aspiration grading of 'Behairy' onion seeds into light, medium, and heavy grades, each representing about one-third of
Table 1. Effect of seed grading on seed weight, germination, emergence, stand, and yield of 'Granex 33' onions (1986).

\begin{tabular}{|c|c|c|c|c|c|c|}
\hline \multirow[b]{2}{*}{ Seed grade } & \multirow[b]{2}{*}{$\begin{array}{l}\text { Seed wt } \\
(\mathrm{mg})\end{array}$} & \multirow{2}{*}{$\begin{array}{c}\text { Germination } \\
\text { at } 10 \mathrm{C} \\
(\%)\end{array}$} & \multicolumn{2}{|c|}{ Field } & \multicolumn{2}{|c|}{$\begin{array}{l}\text { Bulb yield }(\mathrm{kg}) \text { per } 100 \\
\text { seeds } \\
\end{array}$} \\
\hline & & & $\begin{array}{c}\text { Emergence } \\
(\%)\end{array}$ & $\begin{array}{l}\text { Stand } \\
(\%)\end{array}$ & Total & Marketable \\
\hline \multicolumn{7}{|l|}{ Nonaspirated } \\
\hline Nonsized & $2.79 \mathrm{~d}^{2}$ & $81 \mathrm{c}$ & $66 \mathrm{~b}$ & $36 \mathrm{bc}$ & $2.92 \mathrm{c}$ & $2.18 \mathrm{bdc}$ \\
\hline Small & $2.21 \mathrm{~h}$ & $69 \mathrm{~d}$ & $34 \mathrm{e}$ & $13 \mathrm{de}$ & $1.41 \mathrm{de}$ & $1.24 \mathrm{de}$ \\
\hline Large & $2.94 \mathrm{c}$ & $92 \mathrm{~b}$ & $67 \mathrm{~b}$ & $43 \mathrm{~b}$ & $3.70 \mathrm{bc}$ & $3.09 \mathrm{bac}$ \\
\hline \multicolumn{7}{|l|}{ Light } \\
\hline Nonsized & $2.31 \mathrm{~g}$ & $71 \mathrm{~d}$ & $43 \mathrm{~d}$ & $15 \mathrm{~d}$ & $1.21 \mathrm{e}$ & $0.91 \mathrm{ef}$ \\
\hline Small & $1.80 \mathrm{i}$ & $54 \mathrm{e}$ & $19 \mathrm{f}$ & $3 \mathrm{e}$ & $0.16 \mathrm{f}$ & $0.11 \mathrm{f}$ \\
\hline Large & $2.50 \mathrm{f}$ & $84 \mathrm{c}$ & $55 \mathrm{c}$ & $27 \mathrm{c}$ & $1.71 \mathrm{de}$ & $1.23 \mathrm{de}$ \\
\hline \multicolumn{7}{|l|}{ Heavy } \\
\hline Nonsized & $3.31 \mathrm{~b}$ & $93 \mathrm{~b}$ & $83 \mathrm{a}$ & $58 \mathrm{a}$ & $5.49 \mathrm{a}$ & $4.16 \mathrm{a}$ \\
\hline Small & $2.66 \mathrm{e}$ & $94 \mathrm{~b}$ & $62 b c$ & $31 \mathrm{c}$ & $2.58 \mathrm{~cd}$ & $1.97 \mathrm{cde}$ \\
\hline Large & $3.40 \mathrm{a}$ & $98 \mathrm{a}$ & $83 \mathrm{a}$ & $46 \mathrm{~b}$ & $4.18 \mathrm{~b}$ & $3.23 \mathrm{ab}$ \\
\hline \multicolumn{7}{|l|}{ Relationship } \\
\hline to seed weight $\left(R^{2}\right)$ & 1.00 & 0.81 & 0.92 & 0.86 & 0.83 & 0.79 \\
\hline
\end{tabular}

'Means in columns separated by Duncan's multiple range test, $P=0.05$. 
Table 2. Relationship of weight, elemental concentration, and elemental content to seed germination, seedling emergence, final stand, and yield of 'Granex 33' onion.

\begin{tabular}{|c|c|c|c|c|c|}
\hline \multicolumn{6}{|c|}{ Correlation coefficient' } \\
\hline Criterion & $\begin{array}{c}\text { Germination } \\
\text { at } 10 \mathrm{C}\end{array}$ & $\begin{array}{c}\text { Field } \\
\text { emergence }\end{array}$ & $\begin{array}{l}\text { Final } \\
\text { stand }\end{array}$ & $\begin{array}{c}\text { Total } \\
\text { bulb wt }\end{array}$ & $\begin{array}{c}\text { Marketable } \\
\text { bulb wt }\end{array}$ \\
\hline Seed wt & 0.90 & 0.96 & 0.93 & 0.91 & 0.89 \\
\hline $\mathrm{N}(\%)$ & -0.86 & -'0.88 - n & -0.80 & -0.79 & -0.76 \\
\hline $\mathrm{P}(\%)$ & -0.76 & -0.84 & -0.73 & -0.62 & -0.58 \\
\hline $\mathrm{K}(\%)$ & -0.86 & -0.89 & -0.79 & -0.73 & -0.70 \\
\hline $\mathrm{Ca}(\%)$ & -0.68 & -0.59 & -0.53 & -0.58 & -0.58 \\
\hline $\operatorname{Mg}(\%)$ & -0.73 & -0.78 & -0.67 & -0.66 & -0.64 \\
\hline $\mathrm{Mn}(\mathrm{ppm})$ & -0.82 & -0.80 & -0.70 & -0.68 & -0.66 \\
\hline $\mathrm{Cu}(\mathrm{ppm})$ & -0.66 & -0.77 & -0.78 & -0.77 & -0.77 \\
\hline $\mathrm{Zn}(\mathrm{ppm})$ & -0.18 & -0.31 & -0.31 & -0.31 & -0.28 \\
\hline $\mathrm{N}$ (ng/seed) & 0.89 & 0.95 & 0.93 & 0.91 & 0.89 \\
\hline $\mathrm{P}(\mathrm{ng} / \mathrm{seed})$ & 0.88 & 0.93 & 0.93 & 0.93 & 0.93 \\
\hline $\mathrm{K}(\mathrm{ng} /$ seed $)$ & 0.86 & 0.92 & 0.93 & 0.93 & 0.91 \\
\hline $\mathrm{Ca}(\mathrm{ng} /$ seed $)$ & 0.76 & 0.87 & 0.87 & 0.81 & 0.78 \\
\hline $\mathrm{Mg}(\mathrm{ng} / \mathrm{seed})$ & 0.88 & 0.94 & 0.93 & 0.91 & 0.89 \\
\hline Mn (ng/seed) & 0.81 & 0.90 & 0.91 & 0.89 & 0.87 \\
\hline $\mathrm{Cu}(\mathrm{ng} / \mathrm{seed})$ & 0.90 & 0.92 & 0.86 & 0.83 & 0.80 \\
\hline $\mathrm{Zn}$ (ng/seed) & 0.81 & 0.79 & 0.74 & 0.73 & 0.73 \\
\hline
\end{tabular}

${ }^{2}$ Correlation coefficients $>0.38$ and 0.49 significant $\mathrm{a} P=0.05$ and 0.01 , respectively.

Table 3. Effect of aspiration seed grading on seed weight, germination, emergence, stand, and yield of 'Behairy' onions.

\begin{tabular}{lcccccc}
\hline \hline Aspiration & $\begin{array}{c}\text { Germination } \\
\text { grade }\end{array}$ & $\begin{array}{c}\text { Seed wt } \\
(\mathrm{mg})\end{array}$ & $\begin{array}{c}\text { Field } \\
(\%)\end{array}$ & $\begin{array}{c}\text { Final } \\
\text { stand } \\
(\%)\end{array}$ & \multicolumn{2}{c}{$\begin{array}{c}\text { Bulb yield (kg) per 100 } \\
\text { seeds }\end{array}$} \\
\hline None & $4.3 \mathrm{~b}^{\mathrm{z}}$ & $74 \mathrm{~b}$ & $61 \mathrm{c}$ & $33 \mathrm{ab}$ & $1.73 \mathrm{ab}$ & $0.80 \mathrm{a}$ \\
Light & $3.4 \mathrm{c}$ & $58 \mathrm{c}$ & $42 \mathrm{~d}$ & $19 \mathrm{~b}$ & $1.00 \mathrm{~b}$ & $0.30 \mathrm{c}$ \\
Medium & $4.3 \mathrm{~b}$ & $88 \mathrm{a}$ & $69 \mathrm{~b}$ & $35 \mathrm{ab}$ & $1.48 \mathrm{ab}$ & $0.56 \mathrm{~b}$ \\
Heavy & $4.9 \mathrm{a}$ & $89 \mathrm{a}$ & $79 \mathrm{a}$ & $55 \mathrm{a}$ & $2.52 \mathrm{a}$ & $0.80 \mathrm{a}$ \\
\hline
\end{tabular}

'Means in columns separated by Duncan's multiple range test, $P=0.05$.

the seed lot, produced grades with seed weights ranging from 3.4 to $4.9 \mathrm{mg} / \mathrm{seed}$ (Table 3). Weight of the medium-grade seed was the same as that of nongraded seeds. The medium seed grade had higher germination at $10 \mathrm{C}$ and emergence under field conditions at Tifton than the nongraded seeds, but marketable bulb yield of the nongraded seed lot was greater than that of medium- potential. Yield was highly correlated with the weight of the seeds used to establish the stand. Elemental content was consistently higher in the heaviest seed, but elemental concentrations in the seed were generally negatively correlated to seed weight, onion growth, and yield.

\section{Literature Cited}

Austin, R.B. 1963. Yield of onions from seeds as affected by place and method of seed production. J. Hort. Sci. 38:277-285.

Brandenburg, N.R. 1977. The principles and practices of seed cleaning: Separation with equipment that senses dimensions, shape, density and terminal velocity of seeds. Seed Sci. \& Technol. 5:173-186.

Hartwig, E.E. and C.J. Edwards, Jr. 1970. Effects of morphological characteristics on seed yield in soybean. Agron. J. 62:64-65.

Issac, R.A. and W.C. Johnson. 1976. Detemrination of total nitrogen in plant tissue. J. Assn. Offic. Anal. Chem. 59:98-100.

Johnson, D.R. and V.D. Ludders. 1974. Effect of planted seed size on emergence and yield of soybean [Glycine max (L.) Merr]. Agron. J. 66:117-118.

Jones, J. B., Jr. 1977. Elemental analysis of soil extracts and plant tissue ash by plasma emission spectroscopy. Commun. Soil Sci. Plant Anal. 8:349-365.

Smith, O. E., N.C. Welch, and T.M. Little. 1973. Studies on lettuce seed quality: I. Effect of seed size and weight on vigor. J. Amer. Soc. Hort. Sci. 99:529-533.

Smith, T.J. and H.M. Camper, Jr. 1975. Effects of seed size on soybean performance. Agron. J. 67:681-684.

Smittle, D.A. 1982. Radish (Raphanus sativus) growth and yield responses to seed grading by size and aspiration. Seed Sci. \& Technol. 10:199-205.

Smittle, D. A., R.E. Williamson, and J.R. Stansell. 1976. Response of snap beans to seed separation by aerodynamic properties. HortScience 11:469-471.

Vavrina, C.S. and D. Granberry. 1988. Dry bulb onions. Georgia Coop. Ext. Circ. 801. 